\title{
Characterization of Novel Bacteriophages for Biocontrol of Bacterial Blight in Leek Caused by Pseudomonas syringae pv. porri
}

\section{OPEN ACCESS}

Edited by:

Peter Mullany,

University College London, UK

Reviewed by:

Melinda J. Mayer,

Institute of Food Research, UK

Peter Pristas,

Slovak Academy of Sciences, Slovakia

D. Ipek Kurtboke,

University of the Sunshine Coast,

Australia

lan F. Connerton,

University of Nottingham, UK

*Correspondence:

Rob Lavigne

rob.lavigne@kuleuven.be

Specialty section:

This article was submitted to

Antimicrobials, Resistance and

Chemotherapy,

a section of the journal

Frontiers in Microbiology

Received: 17 November 2015

Accepted: 22 February 2016

Published: 15 March 2016

Citation:

Rombouts S, Volckaert $A$

Venneman S, Declercq B,

Vandenheuvel $D$, Allonsius $C N$, Van Malderghem $C$, Jang $H B$, Briers $Y$,

Noben JP, Klumpp J, Van

Vaerenbergh J, Maes $M$ and Lavigne $R$ (2016) Characterization of Novel Bacteriophages for Biocontrol of Bacterial Blight in Leek Caused by

Pseudomonas syringae pv. porri.

Front. Microbiol. 7:279.

doi: 10.3389/fmicb.2016.00279

\section{Sofie Rombouts ${ }^{1,2}$, Anneleen Volckaert ${ }^{3}$, Sofie Venneman ${ }^{4}$, Bart Declercq ${ }^{5}$,} Dieter Vandenheuvel ${ }^{6}$, Camille N. Allonsius ${ }^{6}$, Cinzia Van Malderghem ${ }^{2}$, Ho B. Jang ${ }^{1}$, Yves Briers ${ }^{1,7}$, Jean P. Noben ${ }^{8}$, Jochen Klumpp ${ }^{9}$, Johan Van Vaerenbergh ${ }^{2}$, Martine Maes $^{2,10}$ and Rob Lavigne ${ }^{1 *}$

\footnotetext{
${ }^{1}$ Laboratory of Gene Technology, Department of Biosystems, KU Leuven, Leuven, Belgium, ${ }^{2}$ Unit Plant - Crop Protection, Institute for Agricultural and Fisheries Research, Merelbeke, Belgium, ${ }^{3}$ Vegetable Research Centre (PCG), Kruishoutem, Belgium, ${ }^{4}$ Research Station for Vegetable Production, Sint-Katelijne-Waver, Belgium, ${ }^{5}$ Inagro, Rumbeke, Belgium, ${ }^{6}$ Laboratory of Applied Microbiology and Biotechnology, Department of Bioscience Engineering, University of Antwerp, Antwerpen, Belgium, ${ }^{7}$ Laboratory of Applied Biotechnology, Department of Applied Biosciences, Ghent University, Ghent, Belgium, ${ }^{8}$ School of Life Sciences, Biomedical Research Institute and Transnational University Limburg, Hasselt University, Diepenbeek, Belgium, ${ }^{9}$ Institute of Food, Nutrition and Health, ETH Zurich, Zurich, Switzerland, ${ }^{10}$ Lab. of Microbiology, Department of Biochemistry and Microbiology, Ghent University, Gent, Belgium
}

Pseudomonas syringae pv. porri, the causative agent of bacterial blight in leek (Allium porrum), is increasingly frequent causing problems in leek cultivation. Because of the current lack of control measures, novel bacteriophages were isolated to control this pathogen using phage therapy. Five novel phages were isolated from infected fields in Flanders (vB_PsyM_KIL1, vB_PsyM_KIL2, vB_PsyM_KIL3, vB_PsyM_KIL4, and vB_PsyM_KIL5), and were complemented with one selected host range mutant phage (vB_PsyM_KIL3b). Genome analysis of the phages revealed genome sizes between 90 and $94 \mathrm{~kb}$ and an average GC-content of $44.8 \%$. Phylogenomic networking classified them into a novel clade, named the "KIL-like viruses," related to the Felixounalikevirus genus, together with phage phiPsa374 from $P$. syringae pv. actinidiae. In vitro characterization demonstrated the stability and lytic potential of these phages. Host range analysis confirmed heterogeneity within $P$. syringae pv. porri, leading to the development of a phage cocktail with a range that covers the entire set of 41 strains tested. Specific bio-assays demonstrated the in planta efficacy of phages vB_PsyM_KIL1, vB_PsyM_KIL2, vB_PsyM_KIL3, and vB_PsyM_KIL3b. In addition, two parallel field trial experiments on three locations using a phage cocktail of the six phages showed variable results. In one trial, symptom development was attenuated. These data suggest some potential for phage therapy in controlling bacterial blight of leek, pending optimization of formulation and application methods.

Keywords: Pseudomonas syringae pv. porri, leek bacterial blight, phage therapy, KIL-like viruses, phylogenomics 


\section{INTRODUCTION}

In recent years, an increase in the prevalence of leek bacterial blight was noted in Flanders, Belgium. The disease is caused by the bacterial pathogen Pseudomonas syringae pv. porri, which was first reported in the United Kingdom by Lelliott (1952). Two decades later, the species was isolated in New Zealand by Hale (1975) who further described the pathogen. Later, the bacteria was classified as a new pathovar, $P$. syringae pv. porri, based on extensive research by Samson et al. in France in 1998. Currently, the disease has spread globally and is reported in The Netherlands (Janse, 1982; van Overbeek et al., 2010), Italy (Varvaro, 1983), the United States (Koike et al., 1999), Australia (Noble et al., 2006), Greece (Glynos and Alivizatos, 2006), Japan (Goto, 1972), and Korea (Myung et al., 2011, 2012). Typical symptoms include leaf curling and yellowing of the middle vein in young plants and water soaked spots on older leaves and flowering stems (Samson et al., 1998; Noble et al., 2006). Leek (Allium porrum) is the major host, but the pathogen has also been diagnosed on onion (Allium cepa) and shallot (Allium cepa var. aggregatum; Noble et al., 2006). The disease is known to be transmitted by seed (Koike et al., 1999; Ikene et al., 2003), but crop waste also plays a role in contaminating new leek plants in the field (van Overbeek et al., 2010).

The recent rise in leek bacterial blight is consistent with a growing number of Flemish farmers obtaining leek transplants from plant nurseries. High plant densities in those nurseries, combined with plant manipulations such as irrigation and mowing, promote dissemination of the pathogen among the transplants (Koike et al., 1999). In a previous study, the causative agent of recent leek blight epidemics in Flanders was examined, leading to the proposed subdivision of the strains into two groups, with small genomic differences (Rombouts et al., 2015). Knowledge on this intra-pathovar diversity is important to determine the specificity of phages isolated and characterized within this study.

To date, disease management in leek production mainly consists of prevention. Clean seeds, a strict hygiene in plant nurseries and the use of more tolerant varieties are important control measures. However, once the first symptoms of bacterial blight appear, no solution is available because of the ban on streptomycin derivatives to control bacterial plant diseases in the European Union. The use of copper-based agrichemicals is also undesirable in view of ecotoxicity and bacterial resistance development (Cooksey, 1994; Pietrzak and McPhail, 2004; Hwang et al., 2005). Therefore, the use of phage therapy constitutes an attractive alternative. Bacteriophages are viruses that specifically infect bacteria, their replication resulting in the lysis of their bacterial host and the release of newly formed viral particles. Several reviews have previously been published, highlighting the possibilities and limitations of phage therapy in plant disease control (Gill and Abedon, 2003; Jones et al., 2007; Balogh et al., 2010). In agriculture, phage therapy research has been conducted for pathogens in other crops including "Dickeya solani" (Adriaenssens et al., 2012), Erwinia amylovora (Gill et al., 2003; Boulé et al., 2011), Pectobacterium carotovorum (Ravensdale et al., 2007), Ralstonia solanacearum (Fujiwara et al., 2011), Xanthomonas axonopodis pvs. citri and citrumelo (Balogh et al., 2008), and P. syringae pv. actinidiae (Frampton et al., 2014). To date, phage research resulted in a limited number of commercial phage-based products for agricultural use. These products are for control of two tomato pathogens, Xanthomonas campestris pv. vesicatoria and P. syringae pv. tomato (AgriPhage; Flaherty et al., 2000; Balogh et al., 2003) and against potato rot (Biolyse, APS Biocontrol Ltd.).

Phages infecting $P$. syringae pv. porri have not yet been described. In this manuscript, we focus on the isolation of novel phages which cover the bacterial diversity present in Flemish leek production. Extensive in vitro characterization of the phages was followed by bio-assays and field trials to evaluate the potential of these phages for the biocontrol of bacterial blight in leek.

\section{MATERIALS AND METHODS}

\section{Bacterial Strains and Growth Conditions}

The bacterial strains used in this study are listed in Table $\mathbf{1 .}$ P. syringae pv. porri strains were isolated from fields in Flanders and covered the existing diversity. Their identification and characterization was previously published (Rombouts et al., 2015). These isolates were supplemented with P55, an isolate from soil from the study of van Overbeek et al. (2010), and reference strains of $P$. syringae pv. porri from the Collection Française de Bactéries Phytopathogènes (CFBP; Beaucouzé, France), including the type strain and a set of phylogenetic related strains. Bacteria were grown in lysogeny broth with reduced salt concentration $\left(\mathrm{LB}_{\mathrm{rs}}\right)(0.5 \mathrm{~g} / \mathrm{l} \mathrm{NaCl})$ at $26^{\circ} \mathrm{C}$, or on $\mathrm{LB}_{\mathrm{rs}}$ plates supplemented with $1.5 \%$ agar. $\mathrm{LB}_{\mathrm{rs}}$ with $0.7 \%$ agar (soft agar) was used for the plate overlays.

\section{Bacteriophage Isolation, Amplification, and Purification}

Phages were isolated from soil samples taken in 2011 and 2012, from the same fields from which the $P$. syringae pv. porri strains were isolated. To enrich for phages, a bacterial host (LMG 28495 or LMG 28596) was grown in $25 \mathrm{ml} \mathrm{LB}$ rs at $26^{\circ} \mathrm{C}$ up to exponential growth phase and $5 \mathrm{~g}$ of soil sample was added. After overnight incubation, $250 \mu \mathrm{l}$ chloroform was added and incubation was continued for $1 \mathrm{~h}$ to lyse all bacterial cells. Next, the mixture was centrifuged (30 min, $4500 \mathrm{rpm}$ ) in a Sorvall Legend RT+ centrifuge with swing-out 4-place rotor, type 75006445 (Thermo Scientific, Waltham, MA, USA). The supernatant was filtered through a Millex ${ }^{\circledR}$ syringe filter with a $0.45 \mu \mathrm{m}$ pore size (Merck Millipore Ltd.) and $10 \mu \mathrm{l}$ was spotted on a soft agar layer that contained the bacterial host. Lysis zones were picked up with sterile toothpicks and suspended in phage buffer (10 mM Tris-HCl; pH 7.5; $10 \mathrm{mM} \mathrm{MgSO}_{4} ; 150 \mathrm{mM} \mathrm{NaCl}$ ). These suspensions were plated by pooling $250 \mu \mathrm{l}$ overnight bacterial host culture, $100 \mu \mathrm{l}$ phage suspension and $4 \mathrm{ml} \mathrm{LB}$ rs overlay agar, according to the overlay agar technique (Adams, 1959). After overnight incubation at $26^{\circ} \mathrm{C}$, single plaques were picked up again. Three successive single plaque isolations were performed to achieve pure phage isolates. Based on their DNA restriction pattern (data not shown) different phages were selected for further analysis.

One bacteriophage (KIL3b) was obtained after a co-cultivation experiment. This experiment consisted of the infection of an 
TABLE 1 | P. syringae pv. porri strains and related P. syringae pathovars with their phage sensitivity and BOX-PCR profiles.

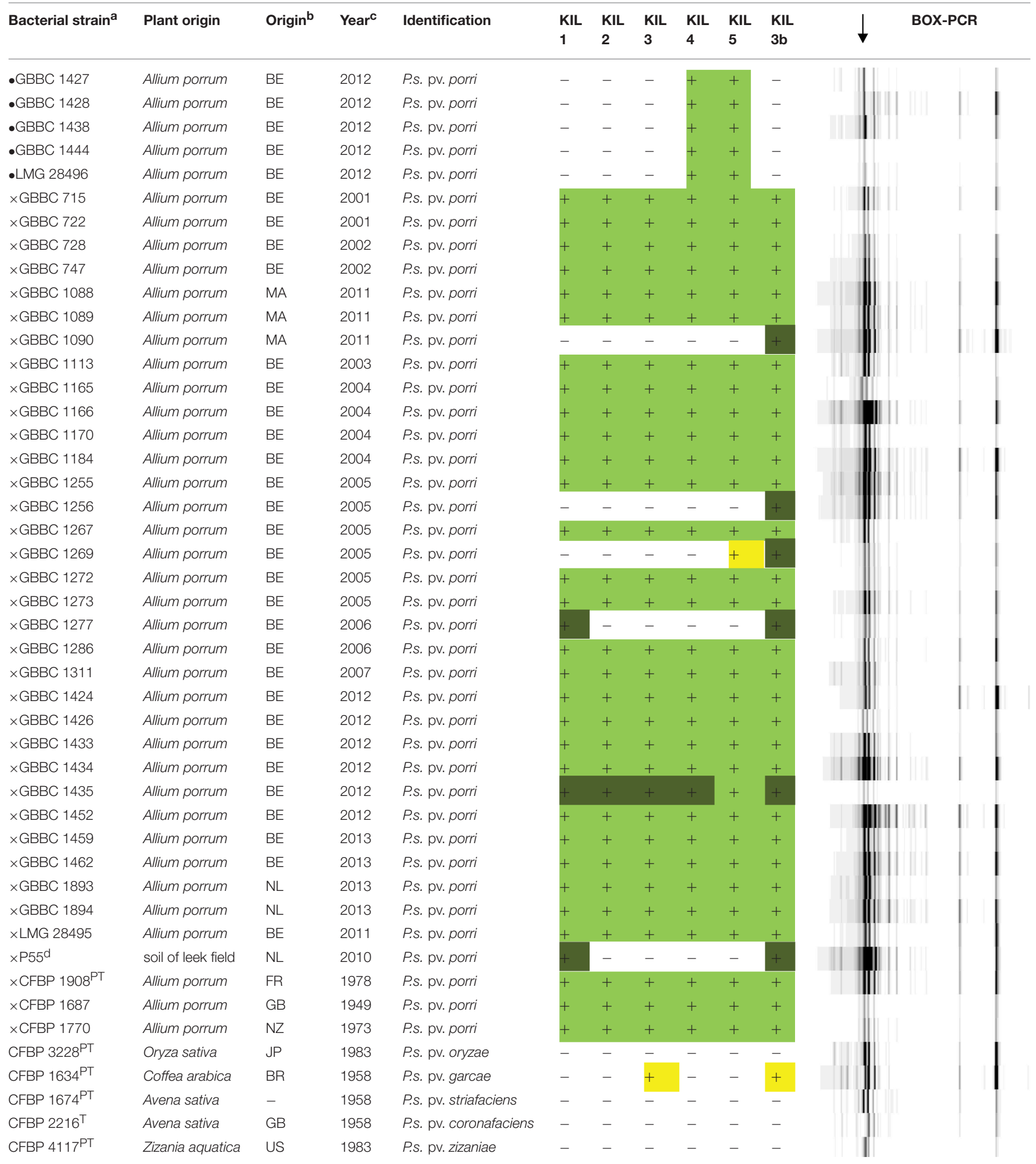

The two symbols ( $\bullet$ and $x$ ) indicate two BOX-PCR pattern groups. The arrow gives the position of the discriminative band. Light and dark green: lysis after 24 and $48 \mathrm{~h}$, respectively and yellow: Iysis from without. ${ }^{a}$ GBBC: culture collection of plant pathogenic bacteria at ILVO; CFBP, Collection Française de Bactéries Phytopathogènes; INRA Angers; LMG, Belgian Coordinated Collections of Microorganisms at the Laboratory of Microbiology of Ghent University with ${ }^{T}$ as type strains and ${ }^{P T}$ as pathovar reference strains. ${ }^{b}$ Geographical origin.

cYear of isolation. ${ }^{d}$ received from van Overbeek et al. (2010). 
TABLE 2 | Bacterial host of the new bacteriophages and phage genome characteristics determined by bioinformatic analysis.

\begin{tabular}{|c|c|c|c|c|c|c|c|c|}
\hline $\begin{array}{l}\text { Phage } \\
\text { name }\end{array}$ & $\begin{array}{l}\text { GenBank } \\
\text { accession number }\end{array}$ & $\begin{array}{l}\text { Bacterial } \\
\text { host }\end{array}$ & $\begin{array}{c}\text { Genome } \\
\text { length (bp) }\end{array}$ & $\begin{array}{c}\text { GC content } \\
(\%)\end{array}$ & \# ORFs & \# tRNAs & Terminators & $\begin{array}{c}\text { Bacterial } \\
\text { promoters }\end{array}$ \\
\hline KIL1 & KU130126 & CFBP 1687 & 90695 & 44.86 & 159 & 5 & 18 & 57 \\
\hline KIL2 & KU130127 & CFBP 1687 & 92466 & 44.79 & 163 & 9 & 17 & 59 \\
\hline KIL3 & KU130128 & CFBP 1687 & 92089 & 44.74 & 161 & 5 & 17 & 61 \\
\hline KIL4 & KU130129 & LMG 28496 & 92825 & 44.89 & 167 & 9 & 18 & 60 \\
\hline KIL5 & KU130130 & LMG 28496 & 93384 & 44.97 & 169 & 9 & 18 & 59 \\
\hline KIL3b & KU130131 & CFBP 1687 & 92099 & 44.72 & 161 & 5 & 17 & 61 \\
\hline
\end{tabular}

exponentially growing liquid culture of $P$. syringae pv. porri strain CFBP 1687 with phage KIL3 at a multiplicity of infection (MOI) of 0.01 . For 4 weeks, $40 \mu \mathrm{l}$ of the liquid culture was transferred to a tube with $4 \mathrm{ml}$ fresh $\mathrm{LB}_{\mathrm{rs}}$ medium every 2 to 3 days and incubated at room temperature. Supernatant of every two-dayold liquid culture was spot tested against the bacterial strain P55 to select for a broadened lytic activity as none of the other phages were able to lyse this strain.

Phages were amplified by plating $10^{5}$ plaque forming units (pfu) per plate together with their bacterial host on a soft agar overlay plate. After overnight incubation at $26^{\circ} \mathrm{C}$, the soft agar was scraped off and suspended in phage buffer. Soft agar and cell debris were subsequently removed by centrifugation $(20 \mathrm{~min}$, $4000 \mathrm{rpm}$ ) in a Sorvall Legend RT+ centrifuge. The supernatant was filtered over a $0.22 \mu \mathrm{m}$ membrane Millex ${ }^{\circledR}$ syringe filter (Merck Millipore Ltd.), after which polyethylene glycol (PEG) 8000 (Sigma-Aldrich) containing $1 \mathrm{M} \mathrm{NaCl}$ was added to the suspension to a final concentration of $8 \% \mathrm{w} / \mathrm{v}$. After minimum $3 \mathrm{~h}$ incubation at $4{ }^{\circ} \mathrm{C}$, phages were precipitated by centrifugation $(30 \mathrm{~min}, 4600 \mathrm{rpm})$ and the pellet was dissolved in $1 \mathrm{ml}$ phage buffer.

Phage purification was performed using CsCl-gradient ultracentrifugation. A phage suspension $(15 \mathrm{ml})$ with a minimum concentration of $10^{10} \mathrm{pfu} / \mathrm{ml}$ was layered on a CsCl step

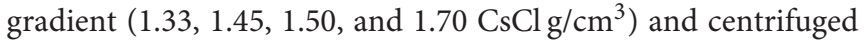
$(3 \mathrm{~h}, 140.000 \times \mathrm{g})$ with a Beckman Coulter Optima L-90K ultracentrifuge (rotor type SW28) (Brea, CA, USA). All phages were collected at the interface between the 1.45 and $1.50 \mathrm{~g} / \mathrm{cm}^{3}$ density layer and dialyzed three times for $30 \mathrm{~min}$ against 300 volumes of phage buffer.

\section{Electron Microscopy}

To obtain transmission electron microscopy (TEM) images of the bacteriophages, dilutions of the samples were spotted on carbon coated grids (Quantifoil, Großlöbichau, Germany) after glow-discharge, and negatively stained with $2 \%$ uranyl acetate. A Philips CM12 microscope was used at $120 \mathrm{kV}$ acceleration voltage. Images were produced using a Gatan Orius $1 \mathrm{k}$ camera.

\section{Host Range Analysis and General Characterization}

Phage host range was tested by spotting a phage suspension on plates with a soft agar layer supplied with a specific bacterial isolate. For all the phages, three different concentrations, ranging from $10^{2}$ to $10^{6} \mathrm{pfu} / \mathrm{ml}$, were tested to determine infectivity. The bacterial strains used in the host range assay are listed in Table 1.

Adsorption experiments were performed according to Adriaenssens et al. (2012). Briefly, bacteria and phage were mixed at an MOI of 0.0001 . Next, samples were taken every minute and bacteria were immediately lysed by adding chloroform. The upper phase was titred to determine the number of non-adsorbed phages.

Killing curves at different MOIs were generated by infecting a bacterial culture at an optical density at $600 \mathrm{~nm}\left(\mathrm{OD}_{600}\right)$ of 0.3 . The $\mathrm{OD}_{600}$ of infected and uninfected cultures was monitored every $20 \mathrm{~min}$ during $6 \mathrm{~h}$. $\mathrm{OD}_{600}$ results were the average of three independent biological repeats.

Phage stability was tested by incubating a phage suspension of $10^{6} \mathrm{pfu} / \mathrm{ml}$ in phage buffer at different temperatures $(-20$, $4,16,30,37$, and $50^{\circ} \mathrm{C}$ ) and at different $\mathrm{pH}$ ranging from 1 to 13 (universal buffer consisting of $150 \mathrm{mM} \mathrm{KCl}$, Janssen Chimica, Geel, Belgium; $10 \mathrm{mM} \mathrm{KH_{2 }} \mathrm{PO}_{4}$, VWR International, Leuven, Belgium; $10 \mathrm{mM}$ sodium citrate, Acros Organics; $10 \mathrm{mM}$ $\mathrm{H}_{3} \mathrm{BO}_{3}$, Acros Organics; adjusted to $\mathrm{pH} 1-13$ with $\mathrm{NaOH}$, or $\mathrm{HCl})$. Infectivity of the phages at different temperatures was tested by incubating soft agar plates with spots of different phage concentrations at room temperature $\left( \pm 21^{\circ} \mathrm{C}\right), 26$ and $30^{\circ} \mathrm{C}$ and counting the infective phage titers.

The frequency of bacterial resistance was determined using an adaptation of a previously developed method (Beale, 1948). Using the agar overlay method, phage and bacteria were plated at MOI 1 and MOI 10, in order to lyse all bacteria on the plate. After $72 \mathrm{~h}$ of incubation, emerging colonies were counted and about 20 colonies were cultured and re-tested for resistance against the phages in Table 2. Phage-resistant isolates were plated on Pseudomonas agar F (PAF, Becton Dickinson) supplemented with glycerol to check for fluorescence under UV-light and analyzed with a multiplex PCR containing specific primers (Ineke Wijkamp, Rijkzwaan, personal communication) to confirm their $P$. syringae pv. porri identity.

Lysogeny in these resistant bacteria was tested as previously described (Petty et al., 2006). Supernatant from overnight cultures of resistant bacteria were collected and tested for the spontaneous release of phage particles by spotting $5 \mu \mathrm{l}$ drops onto soft agar containing the different bacterial hosts. The supernatants from CFBP 1687 and LMG 28496 were used as negative controls, and pure phage solutions $\left(10^{6} \mathrm{pfu} / \mathrm{ml}\right)$ were used as positive controls for plaque formation. 


\section{Genome and Proteome Analysis DNA Isolation and Sequencing}

Contaminating bacterial DNA was removed from phage lysates by DNase treatment. Upon inactivation of the DNase by the addition of EDTA, phage particles were disrupted by adding SDS and proteinase K. The released phage DNA was purified by standard phenol-chloroform extraction and subsequent ethanol precipitation according to Sambrook and Russell (2001). DNA concentration and purity was verified with the NanoDrop ND1000 spectrophotometer (Thermo Fisher Scientific Inc.). DNA integrity and genome size was evaluated on an $0.8 \%$ agarose gel. High throughput sequencing was done using the Illumina MiSeq platform. A $2^{*} 250 \mathrm{bp}$ paired-end library was prepared for each sample, tagged with a unique adapter sequence. The quality of each library preparation was controlled using the Agilent Bioanalyzer. All library preps were equally pooled and sequenced. After processing, the reads of every library prep were assembled in a single contig with a general coverage over 1000x using the CLC Bio Genomics Workbench de novo assembly algorithm (version 7.5.1) (Aarhus, Denmark).

\section{"In silico" Analysis}

The genomes were scanned for open reading frames (ORFs) with GeneMark.hmm and GeneMarkS software (Lukashin and Borodovsky, 1998; Besemer et al., 2001). Shine-Dalgarno sequences were verified manually upstream of each annotated ORF. Functional annotation was carried out by comparing translated ORFs in a Blastp analysis (Altschul et al., 2005) against the nonredundant GenBank protein database and with the Protein Homology/analogY Recognition Engine v2.0 (PHYRE2) (Kelley and Sternberg, 2009). tRNAs were detected with the programs ARAGORN and tRNAscanSE (Lowe and Eddy, 1997; Laslett and Canback, 2004). Rho-independent terminators were predicted with ARNold, a search program that combines two complementary programs: RNAMotif and Erpin (Gautheret and Lambert, 2001; Macke et al., 2001). Probable promoter sequences were identified by looking for conserved intergenic motifs in the 100 bp upstream of every ORF with MEME and PHIRE (Lavigne et al., 2004; Bailey et al., 2009).

\section{Protein Clustering and Phylogenetic Analysis}

Homologous proteins, deduced from their DNA sequences, were examined in the phages KIL1, KIL2, KIL3, KIL4, KIL5, KIL3b, and a number of fully sequenced bacteriophages using HMMER (version3.0; http://hmmer.janelia.org), together with the ACLAME search (version0.4; http://aclame.ulb.ac.be; as of June 2015). In this manner, we retrieved a total of 4632 predicted protein sequences represented in the genomes of the 26 relevant phages (Table S2). We performed pairwise similarity comparisons for each predicted protein by using the ACLAME database with the database of "viruses" and an E-value $<0.001$ (Lima-Mendez et al., 2008). The remaining proteins which could not be assigned into any ACLAME protein family were defined as the unclassified protein families (UPFs) as previously described (Jang et al., 2013). The protein families that were common to all 32 representative phage genomes were identified and their phylogenetic relationships were inferred. After multiple sequence alignment of the conserved proteins using CLUSTALW2, noninformative positions were excluded with the BMGE software package (Criscuolo and Gribaldo, 2010). The two alignments were then concatenated into a FASTA file and a phylogenetic tree was built with MEGA5 (version 5.2.1; http://www.megasoftware. net/; Tamura et al., 2011) using a Jones-Taylor-Thornton (JTT) model. To estimate the robustness of the trees, we used the maximum-likelihood algorithm provided with bootstrap support ( $n=1000$ replicates).

\section{Proteome Analysis}

Structural proteins of phages KIL3 and KIL5 were identified by SDS-PAGE gel electrophoresis, isolation of gel bands, and subsequent trypsinization and ESI-MS/MS as described previously (Lavigne et al., 2009a). The resulting data were analyzed using Mascot (version 2.3.01) and Sequest (version 1.2.0.208), against a database containing all possible ORFs based on the DNA sequence of the phages.

\section{Phage Therapy Experiments Bio-Assay}

In planta activity of the phages was tested by injecting phage and bacterial suspensions into leek leaves. Leek plants of the disease susceptible cultivar Krypton (Nunhems) were grown in separate pots until full development of three leaves. Next, $0.1 \mathrm{ml}$ of bacterial suspension was injected with a syringe into the middle of the leaf. Subsequently, $3 \mathrm{~cm}$ above the bacterial injection place $0.1 \mathrm{ml}$ of phage suspension $\left(10^{9} \mathrm{pfu} / \mathrm{ml}\right)$ was injected (Supplementary Figure 1). In the first bio-assay all 41 P. syringae pv. porri strains $\left(10^{7} \mathrm{CFU} / \mathrm{ml}\right)$ were inoculated in leek leaves (three inoculated leaves/strain) and all phage types $\left(10^{9} \mathrm{pfu} / \mathrm{ml}\right)$ were co-inoculated with a $P$. syringae pv. porri representative (eight inoculations/phage-bacteria combination). This experiment was repeated using the disease susceptible cultivar Striker (Bejo) and a lower bacterial concentration $\left(10^{6}\right.$ $\mathrm{CFU} / \mathrm{ml})$. Phages KIL1, KIL2, KIL3, and KIL3b $\left(10^{9} \mathrm{pfu} / \mathrm{ml}\right)$ were co-inoculated with bacterial strain CFBP 1687 and phages KIL4 and KIL5 with LMG 28496 (10 inoculations/phage-bacteria combination). Plants were covered for $48 \mathrm{~h}$ with a plastic bag to maintain humid conditions and kept at a temperature of $25^{\circ} \mathrm{C}$. Lesion lengths were measured after 10 days. Injections with only bacteria, phage or buffer served as controls.

\section{Field Trials}

In a first trial, leek transplants were treated with phages before they were planted in an infested field. First, the field was infested by spraying a solution of CFBP 1687 with a concentration of $10^{6}$ $\mathrm{CFU} / \mathrm{ml}$ on the soil at a rate of $1000 \mathrm{l} / \mathrm{ha}$, at $1.5 \mathrm{bar}$ and with $0.01 \%$ Tween ${ }^{\circledR} 20$ as surfactant. The next day, before planting, leek plants were submerged in a solution containing a mixture of the six different phages, each at a concentration of $10^{7} \mathrm{pfu} / \mathrm{ml}$. Control plants were planted without treatment. Four blocks of the phage-treated and non-treated plants were randomly distributed over the field, with each block containing 300 plants. At multiple time points after planting, disease incidence (number of damaged plants) as well as disease severity (\% of leaf surface affected) was measured for 20-50 plants per block. This trial 
was performed simultaneously on three different locations in Flanders: Kruishoutem, PCG (N 50.94337 ${ }^{\circ}$, E 3.52710 $)$, SintKatelijne Waver, PSKW (N 51.078120 , E 4.528180 $)$, and Beitem, Inagro (N 50.901508 ${ }^{\circ}$, E $3.124464^{\circ}$ ).

In a second trial, leek transplants were planted in a noninfested field. Two months after planting, bacterial infection was performed with strain CFBP 1687. A suspension with a concentration of $10^{6} \mathrm{CFU} / \mathrm{ml}$ was spread over the plants at a rate of $1000 \mathrm{l} / \mathrm{ha}$, at $1.5 \mathrm{bar}$ and with $0.01 \%$ Tween ${ }^{\circledR} 20$ as surfactant. The next day, a mix of the six different phages, each at a concentration of $10^{9} \mathrm{pfu} / \mathrm{ml}$ and supplemented with $0.01 \%$ Tween ${ }^{\circledR} 20$, was sprayed over the plants, in a way that each plant was covered with on average $10^{8}$ pfu of each phage after spraying. Plants were covered with plastic for $48 \mathrm{~h}$ and assessed as described. This trial was also performed in parallel on the three different locations in Flanders mentioned above.

\section{Statistical Analysis of Data}

Statistical analyses were performed with IBM SPSS Statistics 20. For the bio-assays, normality of the data was assessed with the Kolmogorov-Smirnov and Shapiro-Wilk test at a significance level of 0.05 . Homogeneity of variances was tested using the Levene's test. When the data were distributed normally and homoscedasticity was proven, an one-way ANOVA test was performed to check for differences. If the tests showed significant differences, the data were further analyzed with a post-hoc Tukey HSD test. To test for differences between groups of not normally-distributed data, a Kruskal-Wallis non-parametric test was used. When differences were present, Mann-Whitney U nonparametric test was used to compare the groups, paired two by two. For the field trials, the statistical program ARM (version 2015.3) was used. This program, which is designed specifically for field trials, uses the Bartlett's test to test the homogeneity of variances and the Kurtosis and Skewness tests to check normality. One-way ANOVA with the post-hoc Duncan test was used for normal distributed and homoscedastic data. As a non-parametric test, the Friedman test was applied to check for differences between several variables.

\section{RESULTS}

\section{Phage Isolation and TEM}

Phages were isolated from soil samples taken in 2011 and 2012 from the same fields from which $P$. syringae pv. porri isolates were obtained (Table 2). After enrichment of the phages present in the soil, their capacity to lyse P. syringae pv. porri strain CFBP 1687 was tested. Based on their differential DNA restriction pattern (data not shown) phages were selected for further analysis. By this method, five novel phages were discovered for P. syringae pv. porri and the phages were named KIL1, KIL2, KIL3, KIL4, and KIL5 (referring to the involved research institutes KU Leuven and ILVO) with scientific names vB_PsyM_KIL1 etc. as proposed by Kropinski et al. (2009). The host strains used for amplification and characterization of each of these phages are indicated in Table 2.

TEM images of a phage representative revealed that they belong to the Myoviridae family with morphological similarity

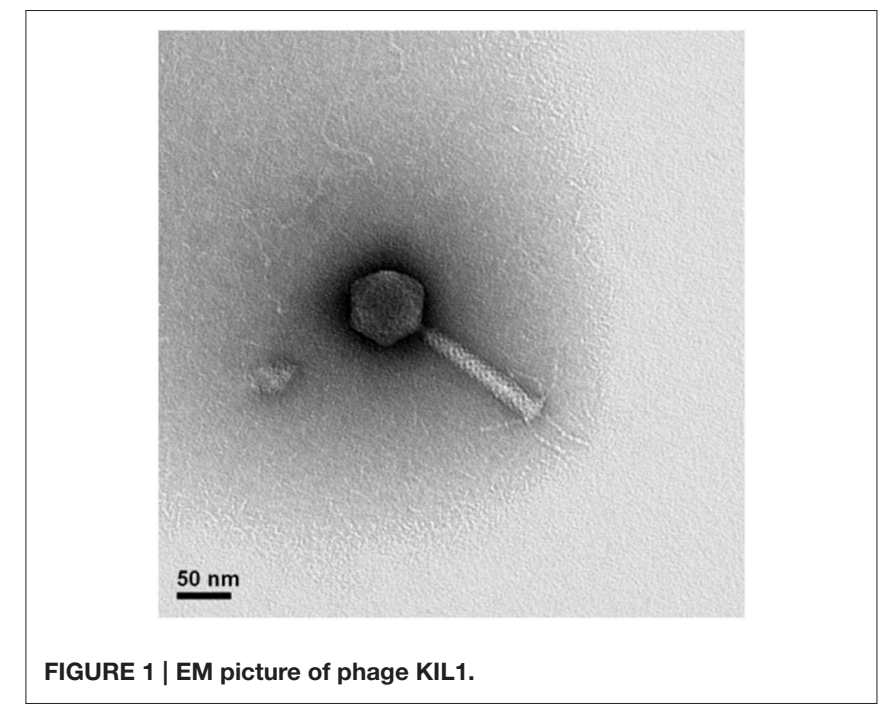

to the Pseudomonas phage PB1 (genus Pbunalikevirus), as shown for phage KIL1 in Figure 1. The other analyzed phages have an identical morphology.

\section{Host Range Analysis}

To investigate the specificity of the phages, a host range analysis was performed (Table 1), by using standard serial dilution spotting assays to distinguish infection from lysis from without phenomena, as described previously (Adriaenssens et al., 2012). Some of the bacterial isolates could not be infected by our five phage isolates from soil, therefore the host-range mutant phage KIL3b was developed. The results indicate that the bacterial strains can be divided in three groups. One group consists of five field isolates from the year 2012 and was only infected by phages KIL4 and KIL5. A second group of strains was infected by all the investigated phages and a third group of strains only showed lysis after $48 \mathrm{~h}$ and by a limited number of phages. None of the pathovars related to $P$. syringae pv. porri was infected by the phages demonstrating their specificity for pathovar porri. However, P. syringae pv. garcae (CFBP 1634) showed "lysis from without" at phage concentrations of $10^{6} \mathrm{pfu} / \mathrm{ml}$. In addition, none of the phages infected all $P$. syringae pv. porri strains tested but the combined host range of the phages covers all 41 isolates tested. A previous BOX-PCR analysis on DNA of all the bacterial strains used in the host range analysis provided information about their genomic diversity and identified two groups within P. syringae pv. porri (Rombouts et al., 2015). These two groups were confirmed by phage profiling, suggesting that differences in the bacterial genome are responsible for the observed host range. Two phages, KIL3 and KIL5 were selected for further characterization.

\section{General Characteristics}

To assess the infection parameters, adsorption experiments were performed for phage KIL3. On average, $84 \%$ of phages were irreversibly adsorbed to the host cell after $1 \mathrm{~min}$ and $99 \%$ after 6 min with an adsorption constant $\mathrm{k}\left[\mathrm{k}=\left(2.3 /\left(\mathrm{B}^{*} \mathrm{t}\right)\right)^{*} \log \left(\mathrm{P}_{0} / \mathrm{P}\right)\right.$, with $\mathrm{B}$ the bacterial titer at time zero, $\mathrm{P}$ the phage titer and $\mathrm{t}$ 
the time] at $1 \mathrm{~min}$ of $7.52 \times 10^{-9} \mathrm{ml} / \mathrm{min}$. Compared to other Myoviridae phages, this is slower than reported for phage T4 $\left(2.4 \times 10^{-9} \mathrm{ml} / \mathrm{min}\right)$ but comparable to the adsorption constants of phages LIMEstone1 $\left(9.53 \times 10^{-9} \mathrm{ml} / \mathrm{min}\right)$ and LIMEstone2 $\left(2.05 \times 10^{-8} \mathrm{ml} / \mathrm{min}\right)$ infecting Dickeya (Kasman et al., 2002; Adriaenssens et al., 2012).

Killing curves generated by infecting an exponentially growing cultures of $P$. syringae pv. porri CFBP 1687 and LMG 28496 with phages KIL3 and KIL5, respectively, at different MOI demonstrated their virulence (Supplementary Figure 2). Optical density of the bacterial cultures at $600 \mathrm{~nm}$ decreased after 80 and 100 min for phage KIL3 and KIL5, respectively. KIL5 showed a later but steeper decline reaching $\mathrm{OD}_{600}<0.1$ after $180 \mathrm{~min}$ instead of $220 \mathrm{~min}$ for KIL3. No rise in $\mathrm{OD}_{600}$ appeared within the $5 \mathrm{~h}$ of monitoring indicating that resistance did not develop at that point.

The influence of temperature and $\mathrm{pH}$ on the viability was tested. As shown for KIL3 and KIL5 (representatives of the two phage clades in the cocktail), the phages were stable between 4 and $37^{\circ} \mathrm{C}$ in phage buffer for $24 \mathrm{~h}$, but after $24 \mathrm{~h}$ of incubation at $50^{\circ} \mathrm{C}$, a two and one $\log _{10}$ unit decrease was noted for phage KIL3 and KIL5, respectively. After freezing, all viable KIL3 phages were lost, while the titer of KIL5 decreased by three $\log 10$ units. Phages were stable from $\mathrm{pH} 4$ to 12 for $24 \mathrm{~h}$.

An analysis of the optimal infection temperature revealed that none of the phages are able to infect their host when grown at temperatures of $30^{\circ} \mathrm{C}$. Phages KIL1, KIL2, KIL3, KIL4, and KIL5 were able to infect at temperatures of $26^{\circ} \mathrm{C}$ and room temperature $\left( \pm 21^{\circ} \mathrm{C}\right)$, and KIL3b only infected at room temperature.

For two phage-host interactions, frequency of bacterial resistance development was determined. An exponentially growing culture of strain CFBP 1687 was infected with KIL3 at MOI 1 and after $72 \mathrm{~h}$ incubation, an average of 110 phageresistant bacteria appeared on plate. To exclude the possibility of contamination, the identity of 12 colonies was verified with PCR-analysis using specific primers, confirming their identity as $P$. syringae $\mathrm{pv}$. porri. This resulted in a resistance frequency of $1.83 \times 10^{-6}$. A host screen with those resistant bacterial derivatives revealed that five of them were resistant to the six phages, a phenomenon called cross-resistance. The other isolates could still be infected by the host-range mutant phage KIL3b. The same experiment was performed with phage KIL4. After $72 \mathrm{~h}$ incubation on average 200 resistant colonies appeared and PCRanalysis was used to confirm the identity of 12 of them, resulting in a calculated resistance frequency of $3.33 \times 10^{-6}$. Again, crossresistance was observed for part of the strains (four out of 12), the other resistant strains were still infected by KIL3b.

A spot test with supernatant from an overnight culture of those resistant isolates on strains CFBP 1687 and LMG 28496 suggested there was no induction of lysogens under the conditions tested. In general, as all phages produced clear plaques there was no indication for lysogeny.

\section{Genome and Proteome Analysis Genome Analysis}

The genomes of all six phages were sequenced using the Illumina MiSeq platform and single contigs were obtained. Information about the genome characteristics of the phages is summarized in Table 2.

ORFs were identified and similarity at the protein level was verified by Blastp analysis. In addition, a putative function could be assigned to some ORFs without homologs using PHYRE2. All tRNAs were found in the same region spanning $2.7 \mathrm{~kb}$ in front of the large terminase subunit, a part of the packaging machinery (Figure 2). This is consistent with the genome organization of the related PAK_P1-like phages (Debarbieux et al., 2010; Henry et al., 2015). When comparing the tRNAs present in the six genomes, phages KIL1, KIL3, and KIL3b encode the same five tRNAs. KIL2, KIL4, and KIL5 also have these five tRNAs in their genomes, supplemented with four additional tRNAs. Depending on the phage, 17 or 18 rho-independent terminators were retained after manual verification and were located across the entire genome. Probable promoter sequences were identified by looking for conserved motifs in the $100 \mathrm{bp}$ upstream region of every ORF. Using MEME, a motif resembling a typical E. coli bacterial promoter sequence (TTGACA-N $\mathrm{N}_{17-18}$-TATAAT) was found in all phages. As in the most closely related $P$. syringae phage PhiPsa374, the 41 bp conserved motif surrounding the bacterial promotor sequences in PAK_P1-like viruses was not encountered thereby confirming its specificity for P. aeruginosa phages (Henry et al., 2015). No toxin genes, virulence genes or genes related to lysogeny were discovered in the phage genomes, indicating their suitability for phage therapy.

A remarkable feature of all KIL-like phages is the presence of a homopolymeric G-stretch of variable length at one or two locations in the genome (Table S1). Illumina reads at those positions contain 6-13 Gs. Both stretches are found in intergenic regions, yet not clearly associated to known promoter elements. A similar feature was reported previously in PB1-like phages, in a sequence coding for a baseplate protein and in the ORF coding for a DNA adenine methylase in Bordetella phages BPP-1, BIP-1, and BMP-1 (Liu et al., 2004; Ceyssens et al., 2009). It was proposed that the resulting frameshift serves as a control point for expression levels of the protein. Another remarkable region in the KIL-like phage genomes is a long Astretch varying from 14 to 33 nucleic acids in length. In the most related phage phiPsa374 those homopolymeric stretches are not present. A phylogenetic analysis of the six phages based on their genome sequences confirms the subdivision of the phages into two groups, correlated to their host range. The first group constitutes of phage KIL1, KIL2, KIL3, and KIL3b, the second group contains phages KIL4 and KIL5. Between the groups, some differences in the ORFs are predicted, mostly among unknown genes. The difference between the genomes of phage KIL3 and KIL3b, which is a host range mutant of the former, is limited to the number of repeats located in the homopolymeric A- and Gstretches. No clear biological function could be attributed to this phenomenon.

\section{The Phylogenetic and Proteome-Based Relationships}

To further frame these phages in their comparative genomic context, phylogenetic trees were constructed based on the concatenated datasets of two structural genes encoding the major capsid protein and the baseplate protein. These two proteins 


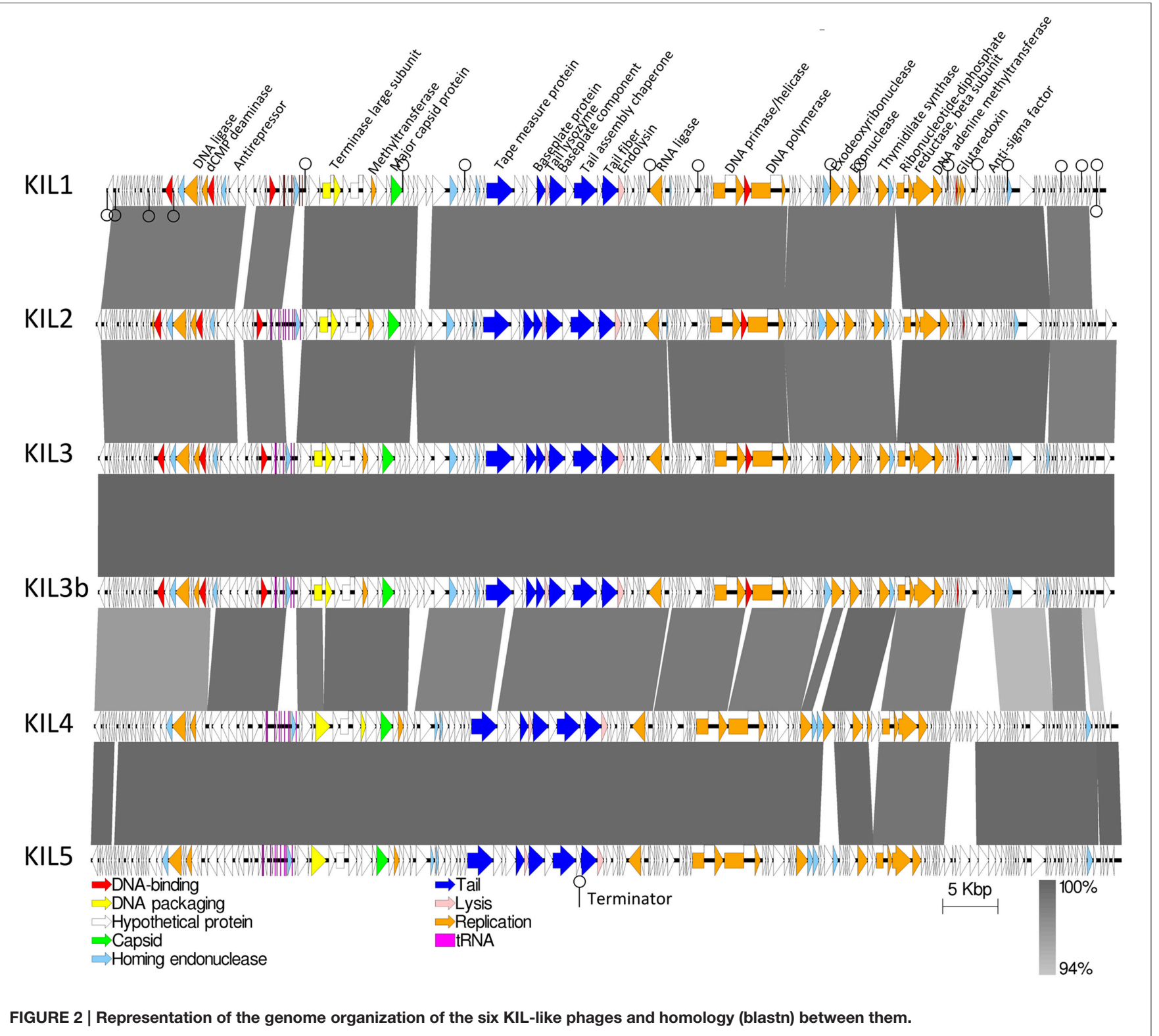

are shared among the genomes of four clades: the FelixO1like viruses, PAK_P1-like viruses, and KPP10-like viruses within the Felixounalikevirus genus and the rV5-like viruses, as well as phages CR3, ICP1, and our six phage isolates. Each protein was assigned to "Family:virus:314" and "Family:virus:3622" by ACLAME-based clustering (Table S2). Phylogenetic analysis revealed the four clades comprising the KPP10-, PAK_P1-, FelixO1, and rV5-like phages, respectively (Left, Figure 3). Most clades branch deeply and are well supported with bootstrap support values of more than $90 \%$. Within the Felixounalikevirus genus, the Pseudomonas phages KIL1, KIL2, KIL3, KIL4, KIL5, and KIL3b are grouped into a distinct clade, together with a Pseudomonas phage phiPsa374.

To investigate the genome relatedness based on the proportion of conserved homologous proteins between two phages, we performed pairwise comparisons of the 32 phage genomes, which allowed us to assign 5622 protein sequences to 1322 homologous protein families (Table S1). A cut-off value of $40 \%$ of homologous proteins was used to assign phage genomes to a putative genus (Lavigne et al., 2008, 2009b). The pattern of proteome-based grouping was highly similar to our phylogenetic results, in which KIL1, KIL2, KIL3, KIL4, KILP5, KIL3b, and phiPsa374 form a conserved group with $\geq 50 \%$ homologous proteins in common to each other's genome (Right, Figure 3). These seven phages are also related to three groups of the Felixounalikevirus phages, sharing more than 20\% of their homologous proteins, with the PAK_P1-like phages being the closest relatives (average 34\% shared proteins). Notably, of these, phiPsa374 shared the highest overlap percentages of the proteomic content $(\geq 40 \%)$ with the PAK_P1-like phages. 


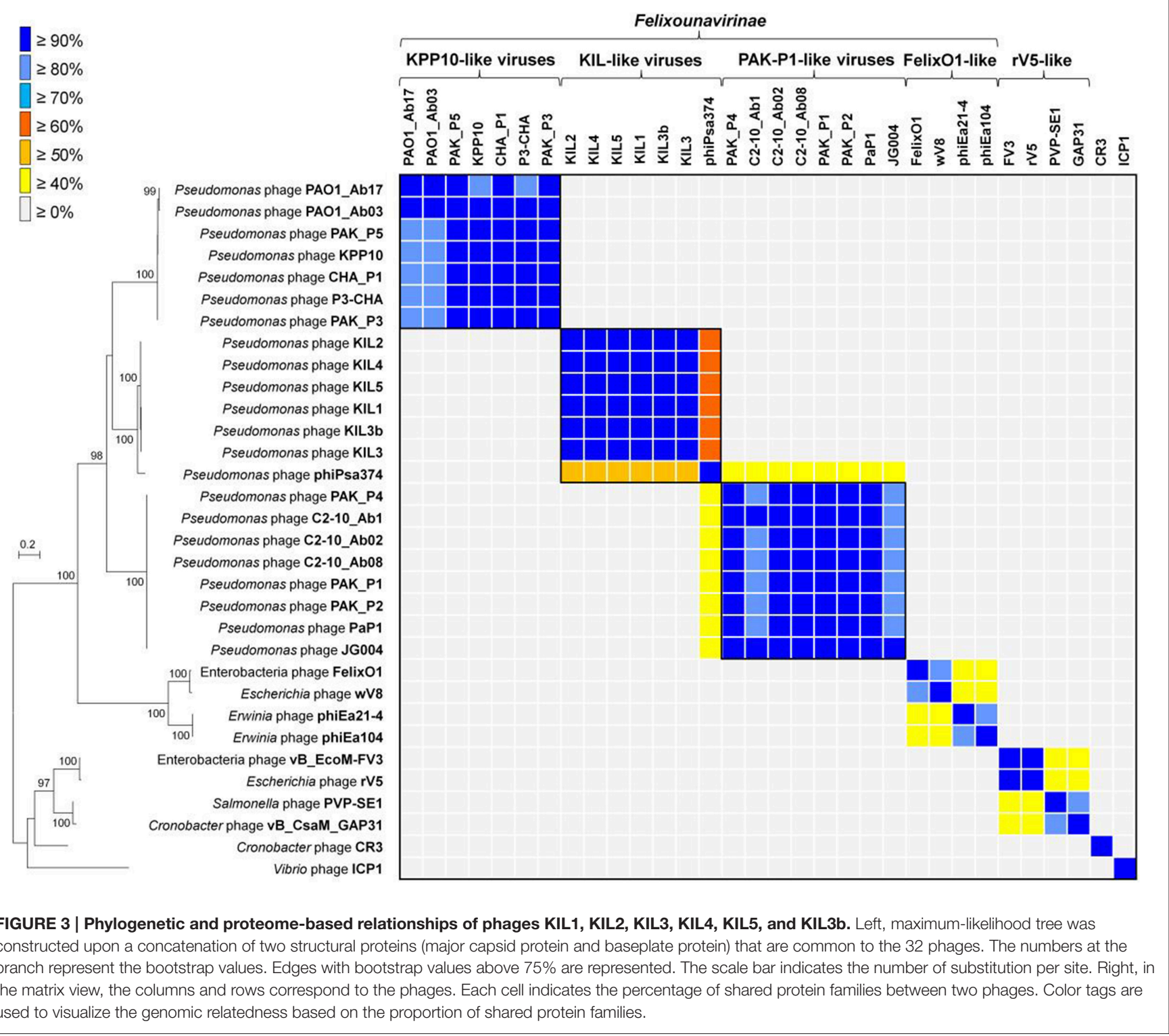

\section{Proteome Analysis}

Analysis of the proteome of phages KIL3 and KIL5 (representatives of the two clades) by ESI-MS/MS led to the identification of 51 and 67 proteins, respectively (Table S3). For KIL3 and KIL5, respectively 27 proteins and 26 had a predicted function based on homology to other phage proteins. In both phages, most of the detected proteins are early phage proteins or structural phage proteins. The use of non CsCl-purified phages might explain the presence of the non-structural phage proteins since they can remain in the phage lysate after bacterial lysis. Alternately, these proteins may be considered as candidate proteins which may be co-injected during infection. The most abundant proteins based on the number of unique peptides recovered are the tape measure protein, ORF 46 (no predicted function) and the major capsid protein in phage KIL3. Similarly, the most abundant proteins of phage KIL5 are the capsid protein,
ORF 46 (no predicted function) and the tail fiber protein (ORF 76). As was seen by Henry et al. (2015) for the related phage PAK_P3, the ORF upstream of the capsid protein had the second highest relative abundance (total number of spectra / Molecular Weight) next to the capsid protein itself, and this in both phages. Although the function of this protein could not be predicted, an association with the capsid protein is suspected. The differences in the number of proteins identified for the two phages could be explained by a difference in protein concentration as the number of peptides recovered for proteins of KIL5 were in general higher than those for KIL3. The identification of these peptides by mass spectrometry confirms the in silico ORF predictions. One structural protein, a tail lysozyme (ORF 70), could not be detected in KIL3; however, the corresponding protein in KIL5 (ORF 71) was identified. All other predicted structural proteins could be experimentally confirmed by mass spectrometry. 


\section{Phage Therapy \\ Bio-Assay on Leek Leaves}

To investigate whether the phages were also capable of lysing their bacterial host in the plant environment, bio-assays were performed on leek leaves.

In a first bio-assay, the bacterial concentration was chosen to be $10^{7} \mathrm{CFU} / \mathrm{ml}$, the amount of bacteria necessary to produce clear symptoms. For the phages, a relatively high concentration of $10^{9} \mathrm{pfu} / \mathrm{ml}$ was used to prove efficacy. All 41 P. syringae pv. porri strains were inoculated and showed comparable virulence, presented on the left side of the boxplot (Figure 4). Strains CFBP 1687 and CFBP 1770 were chosen as representatives of $P$. syringae pv. porri and were used as bacterial host in combination with the different phages. Lesion lengths on the phage treated leaves were compared to the lesion lengths induced by all $P$. syringae pv. porri strains used in this study. In general, each phage reduced the mean lesion length compared to the non-phage treated leaves. The reduction in lesion length was significant for phages KIL1, KIL3, and KIL3b with p-values of $0.003,0.005$, and 0.004 , respectively. Phages KIL2, KIL4, and KIL5 reduced the lesion length, but were not able to prevent bacterial infection completely.

In a second bio-assay, the effect of the phages on a lower bacterial concentration of $10^{6} \mathrm{CFU} / \mathrm{ml}$ was tested using ten leaves per phage. CFBP 1687 was used in combination with phages KIL1, KIL2, KIL3, and KIL3b, phages KIL4 and KIL5 were co-inoculated with bacterial strain LMG 28496. Again, lesion lengths of the phage-treated leaves were compared to the lengths produced by their respective host without phage. As expected, lesion lengths were smaller in all treatments compared to the previous assay with higher bacterial concentrations. Only phages KIL2 and KIL3b decreased lesion length significantly compared to their bacterial control, with $p$-values of respectively 0.042 and 0.006 . Leaves treated with phage KIL3b showed no symptoms for the most part. The results of this second bio-assay confirm that phages KIL4 and KIL5 are less suitable to reduce lesion length significantly. Only phage KIL3b showed significant reduction in both assays, demonstrating its in planta antibacterial effect. The effect of phages KIL1, KIL2, and KIL3 varied between the assays. Nevertheless, it was considered prudent to maintain all phages in a cocktail for subsequent testing in field trials.

\section{Field Trials}

In a first field trial set-up, the potential of phages to protect leek transplants against bacterial infection at planting was tested. Transplants were submerged in a phage solution containing the six phages before planting them in an infested field. This experiment was performed on three different locations in Flanders in the year 2014 (Table 3).

In the trial at PCG, leek plants of cultivar Kenton (Nunhems) were used. The first symptoms developed 25 days after planting in phage-treated and non-treated plants. Two months later, percentages of diseased plants increased to $82 \%$ for the phagetreated plants and $92.5 \%$ for the control plants. Later on, symptoms disappeared again in both groups and percentages of diseased plants were again lower 4 months after planting. The same trend was apparent when scoring the percentage of leaf surface affected.

The same experiment was performed in PSKW with cultivar Harston (Nunhems). Two and three months after planting, the disease incidence was measured. Percentages of symptomatic plants varied from $29 \%$ for the phage-treated plants and 19\% for the control plants after 2 months to 18 and $15 \%$ after 3 months, respectively. No significant differences were observed.

In the experiment at Inagro, leek plants of cultivar Harston (Nunhems) were used. No disease incidence was recorded 2 months after planting. After 3 months, measurements reported an infection rate of $23.5 \%$ of control plants and $18 \%$ for the phage treated plants.

In all three experiments, no significant differences in disease occurrence between treated and untreated plants could be noticed. In the trials performed at PSKW and Inagro, disease incidence remained low indicating that infection was not successful. Conclusions on the efficacy of phage treatment could therefore not be made. From the trial results of PCG we can conclude that phage treatment was not successful in protecting the leek plants from infection when planted in an infested field. However, monitoring at an earlier time-point could be better to detect an effect of the phages. It is also possible that more frequent phage applications are necessary to protect the plants against infection.

In a second field trial, phages were sprayed on artificially infected plants, to test for their potential as a crop protection agent in a later growth stage. First, bacteria were sprayed onto the plants 3 months after planting. The day after, a phage cocktail with the six phages present in a concentration of $10^{9} \mathrm{pfu} / \mathrm{ml}$ each was sprayed onto the plants. Results are shown in Table 4.

In the trial at PCG, again cultivar Kenton (Nunhems) was used and phage treatment was repeated four times every 2 weeks. The first disease assessment was performed 19 days after infection and demonstrated a higher infection rate at the bacteria treated plant in relation to the other plants, meaning that infection was successful. One month after infection, infection rate in the bacteria-treated plants increased and a difference trend could be measured for the phage-treated object in comparison with the non-treated infected object with, respectively, 38.5 and $63 \%$ symptomatic plants. In subsequent measurements this trend continued although the differences became less apparent. The same trend was demonstrated by the data displaying the affected leaf surface. At all time-points, infection was slightly higher in the phage-treated control compared to the untreated plants. The trial demonstrated that phages could decrease symptom development but were not able to completely stop infection. A higher phage concentration and more frequent applications can possibly lead to a better disease control.

The same trial was performed at PSKW with plants of the cultivar Harston (Nunhems). Phage treatments were applied every week for 8 weeks with half the dose of phages compared to the trial of Kruishoutem, meaning that a concentration of $0.5 \times 10^{9} \mathrm{pfu} / \mathrm{ml}$ of each phage was used. Disease incidence was measured one, 2 and 3 months after infection but no differences between the plants could be measured. Even the untreated and infected plants showed the same level of symptoms, indicating 

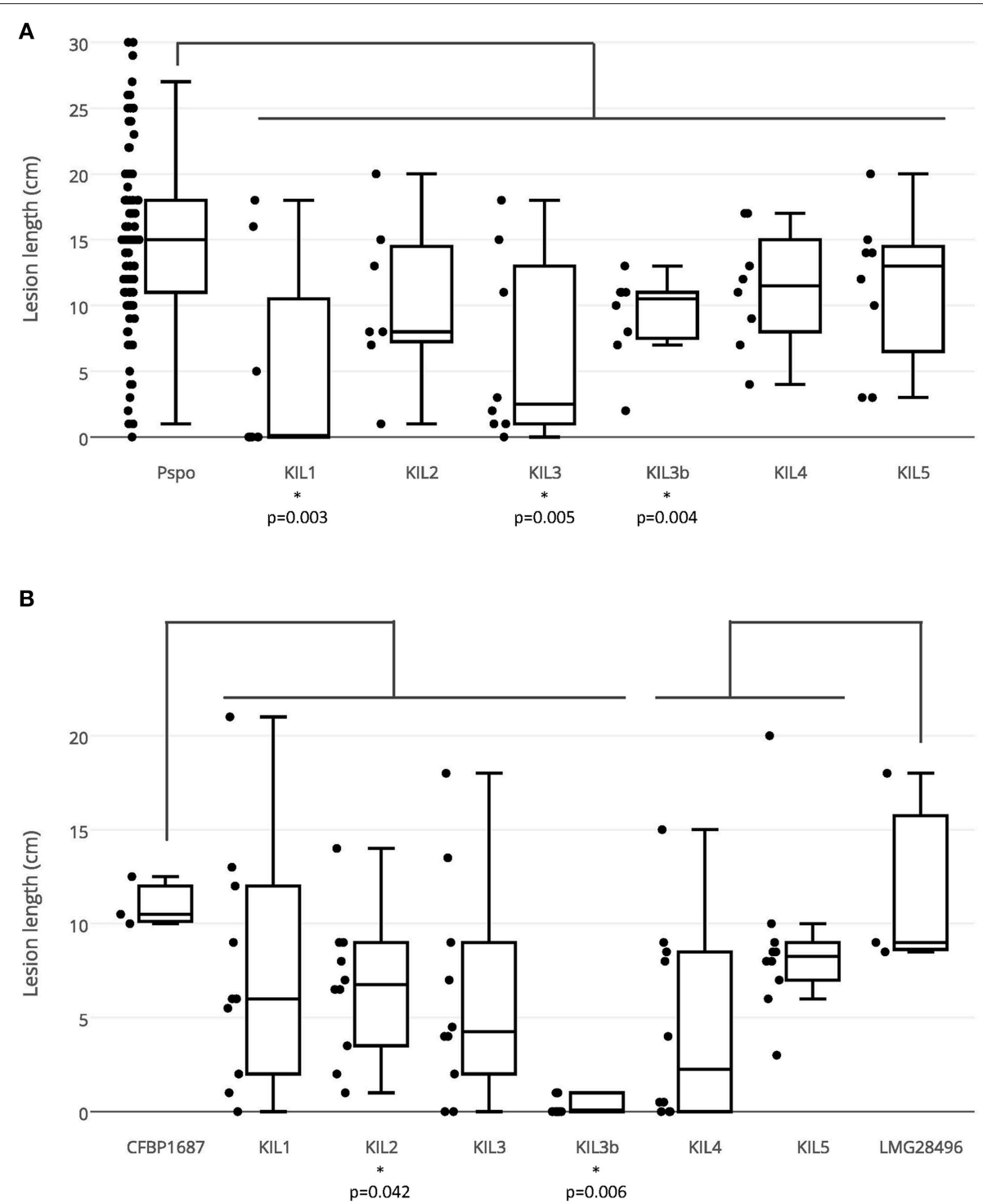

FIGURE 4 | (A) Lesion lengths in the first bio-assay in which all 41 P. syringae pv. porri strains ( $10^{7} \mathrm{CFU} / \mathrm{ml}$ ) were inoculated in leek leaves (three inoculated leaves/strain) and all phage types $\left(10^{9} \mathrm{pfu} / \mathrm{ml}\right)$ were co-inoculated with a $P$. syringae pv. porri representative (eight inoculations/phage-bacteria combination). (B) Lesion lengths in the second bio-assay in which KIL1, KIL2, KIL3, and KIL3b (109 pfu/ml) were co-inoculated with bacterial strain CFBP 1687 (106 $\mathrm{CFU} / \mathrm{ml})$ and phages KIL4 and KIL5 with LMG 28496 (10 inoculations/phage-bacteria combination).

TABLE 3 | Percentage symptomatic plants after 3 months for the field trial at three different locations where 1200 transplants were submerged in phage solution $\left(10^{7} \mathrm{pfu} / \mathrm{ml}\right)$ before planting in a field infested with CFBP 1687.

\begin{tabular}{lccc}
\hline Phage treatment & PCG & PSKW & Inagro \\
\hline No & 92.5 & 15.0 & 23.5 \\
Yes & 82.0 & 18.0 & 18.0 \\
\hline
\end{tabular}

the possibility that symptoms were masked by natural infection with another pathogen.

The trial performed at Inagro used plants of the cultivar Harston (Nunhems). Five phage applications were carried out: one a week before infection, one the evening of the day during which bacterial infection was performed, and three more weekly applications after infection. Two months after infection disease incidence was measured showing no differences between the four treatments. Even the uninfected and untreated control and the uninfected phage-treated control displayed an infection of respectively 19.5 and $24 \%$ indicating the presence of a natural infection that could not be affected by our phages.

Results of the three trials demonstrate that only at PCG conducive conditions for infection with $P$. syringae pv. porri were present. From that trial we can conclude that phage application can lead to a reduction in bacterial disease incidence but cannot 
TABLE 4 | Percentage symptomatic plants after 1 (PCG and PSKW) and 2 months (Inagro) for the field trial with P. syringae pv. porri CFBP $1687\left(10^{6}\right.$ $\mathrm{CFU} / \mathrm{ml})$ and the phage cocktail $\left(10^{9} \mathrm{pfu} / \mathrm{ml}\right)$ being sprayed over 1000 leek plants per treatment.

\begin{tabular}{lrcc}
\hline Treatment & PCG & PSKW & Inagro \\
\hline Untreated & 6.0 & 32.0 & 19.5 \\
Phage & 11.0 & 38.0 & 24.0 \\
Bacteria & 63.0 & 42.0 & 21.5 \\
Bacteria + phage & 38.5 & 30.0 & 19.0 \\
\hline
\end{tabular}

completely prevent it. Other factors such as natural infections with other pathogens make it difficult to predict the effect and reliability of phage therapy in field trials.

\section{DISCUSSION}

The increase of bacterial blight of leek and the related economical losses attracted our interest in the problem a few years ago leading to an extensive investigation of the causative agent, $P$. syringae pv. porri. Previous research divided the Flemish isolates into two groups based on their BOX-PCR fingerprints (Rombouts et al., 2015). Genomic differences among P. syringae pv. porri strains were also described by Noble et al. (2006), who showed minor differences based on profiles generated with IS50-primer amplification and RFLP of a 16S rDNA fragment. In contrast, these authors as well as Koike et al. (1999) and van Overbeek et al. (2010) did not discriminate different genotypes among their isolates from California, Australia and the Netherland when applying different repetitive-element-PCRs (BOX, REP, and ERIC). This overall bacterial diversity was kept in mind when looking for novel phages capable of lysing P. syringae pv. porri. Host range analysis of the five phages isolated from soil and the $\mathrm{H}$-mutant phage confirmed the BOX-PCR grouping of bacterial strains, suggesting that differences at the bacterial genome are responsible for the observed host range. Previous genome analysis of a bacterial strain of each group demonstrated that variation was mostly situated in prophage content and mobile genetic elements (Rombouts et al., 2015). No specific element could be found that linked bacterial diversity with the phage host range. In general, genomic differences can affect phage infection at different stages. If those genome differences result in an altered phage receptor, different receptor binding proteins (RBP) capable of recognizing the altered receptor of the five bacterial strains in group one could be present among the phages KIL4 and KIL5. Changes in host range due to a spontaneous mutation in a tail fiber protein (replacement of a positively charged lysine by an uncharged asparagine) were previously reported for two related phages, Pseudomonas aeruginosa phages PaP1 and JG004 (Le et al., 2013). However, the exact role of the variation and mutation observed here does not lead to a straightforward hypothesis and requires further investigation. In spite of the overall bacteriophage diversity, all phages we found against $P$. syringae pv. porri belong to the Myoviridae family. Genome sequence analysis further classified them into a new clade within the Felixounavirinae genus.
The phage characteristics analyzed in this study show that all six phages are suitable for use in phage therapy. First, they are strictly virulent, meaning that infection with the phages results in bacterial lysis minimizing the risk of horizontal transfer of pathogenicity genes as is the risk with lysogenic phages (Penadés et al., 2015). Furthermore, by demonstrating a temperature stability from 4 to $37^{\circ} \mathrm{C}$ and $\mathrm{pH}$ stability from $\mathrm{pH} 4$ to 12 , they are capable of surviving in the plant environment when applied. However, a disadvantage is their limitation to infect only bacteria grown at temperatures of $28^{\circ} \mathrm{C}$ or lower. This means that in summer, when temperatures occasionally rise above $28^{\circ} \mathrm{C}$ bacteria may not be killed by the phages. Probably, the bacterial receptor necessary for phage infection is not expressed at higher temperatures. Temperature dependent infection was previously reported for phage $\varphi S 1$ which is not able to infect Pseudomonas fluorescens cells grown at $37^{\circ} \mathrm{C}$ (Sillankorva et al., 2004). It has been shown that expression of bacterial genes can be temperature dependent. For example, the expression of flagellar components and the surfactant syringafactin is reduced in $P$. syringae strain B728a at a temperature of $30^{\circ} \mathrm{C}$, resulting in reduced swimming and swarming motility (Hockett et al., 2013). Host range analysis demonstrates that none of the phages is capable of lysing all tested $P$. syringae pv. porri strains, but a combination of different phages in a phage cocktail can cover all strains used. The results indicate that there is some resistance development among $P$. syringae pv. porri strain CFBP 1687 when challenged with the bacteriophages KIL3 or KIL4. Although the kill curves indicate that in the first $5 \mathrm{~h}$ there is no resistance development, after $72 \mathrm{~h}$ an average resistance frequency of around $2 \times 10^{-6}$ was noted. When phages are applied in a phage cocktail, this resistance development is less likely to occur (Gill and Hyman, 2010; Barbosa et al., 2013). The possibility of resistance through lysogenic conversion was excluded, thereby confirming their suitability for phage therapy for this parameter. In addition, development of the host-range mutant phage KIL3b demonstrates that host-range expanding adaptions are possible to counter bacterial resistance, especially because this phage was still able to infect more than half of the resistant bacteria.

To investigate evolutionary relationships of KIL1, KIL2, KIL3, KIL4, and KIL5 with their close relatives, phylogenetic analysis was combined with a whole genome proteomic approach (Lavigne et al., 2008, 2009b). The overall phylogenetic relationships between the concatenated sequences of the major capsid protein and the baseplate proteins of the Felixounalikevirus phages are consistent with previous taxonomic description (Henry et al., 2015). The phages KIL1, KIL2, KIL3, KIL4, and KIL5 as well as phiPsa374 can clearly be grouped into a new phylogenetic clade. Their location within the Felixounalikevirus genus suggests that the sequences of two structural proteins are highly conserved within their own group and appear to be most closely related to those of the "PAK_P1-like viruses" and "KPP1-like viruses." In addition, our proteome-based analysis, which is more sensitive and accurate for taxonomic classification for phage genomes (Lavigne et al., 2008), supports the phylogenetic relationships of the Felixounalikevirus phages. Given that shared homologs between the phage genomes can be used as an indication of 
phage members in the same genus (Lavigne et al., 2008, 2009b), we proposed a possible division of the Felixounalikevirus genus into the four subclades, which include the "KPP10-like viruses" (phages PAO1_Ab17, PAO1_Ab03, PAK_P5, KPP10, CHA_P1, P3-CHA, and PAK_P3), "PAK_P1-like viruses" (PAK_P4, C210_Ab1, C2-10_Ab02, C2-10_Ab-8, PAK_P1, PaP1, and JG004), "FelixO1-like viruses" (FelixO1, wV8, phiEa21-4, and phiEa104), and "KIL-like viruses" (KIL1, KIL2, KIL3, KIL4, KILP5, KIL3b, and phiPsa374). Interestingly, although phage phiPsa374 has been suggested as a member of the PAK_P1-like clade (Frampton et al., 2014; Henry et al., 2015), our results indicate the genome of phiPsa374 aligns with more shared protein families to the KIL-like phages.

No toxin genes, virulence genes or genes related to lysogeny could be discovered in the phage genomes at this time, indicating their suitability for phage therapy. Efficacy of the phages in the plant environment was analyzed with bio-assays in leek leaves. Significant results were only obtained for phages KIL1, KIL2, KIL3, and KIL3b but the broader host range of phages KIL4 and KIL5 led to their incorporation in the phage cocktail for the field trials. When treating transplants with a phage cocktail before planting in an infested field, no significant differences were observed. Spraying of phages on artificially infected plants led to a slightly reduced symptom development in one of the three trials, yet again without statistical significance. Since two trials suffered from natural infections, their impact has most likely masked the effect of the treatments. Although isolation and characterization of phages is reported for several plant pathogens, results of other field trials are scarce. A recent overview has recently been published by Czajkowski (Czajkowski, 2016). A field trial with phages against Dickeya solani on potato also reports of phage therapy resulting in minor differences in disease severity (Adriaenssens et al., 2012). In experiments with phages against $X$. axonopodis pvs citri and citrumelo, significant control of bacterial spot was reported, yet treatment with copper-mancozeb was more effective (Balogh et al., 2008). As other researchers mentioned, open field (and greenhouse) applications with phages encounter many challenges such as

\section{REFERENCES}

Adams, M. H. (1959). Bacteriophages. New York, NY: Interscience Publishers Inc. Adriaenssens, E. M., Van Vaerenbergh, J., Vandenheuvel, D., Dunon, V., Ceyssens, P. J., De Proft, M., et al. (2012). T4-Related Bacteriophage LIMEstone Isolates for the Control of Soft Rot on Potato Caused by 'Dickeya Solani.' PLoS ONE 7:e33227. doi: 10.1371/journal.pone.0033227

Altschul, S. F., Wootton, J. C., Gertz, E. M., Agarwala, R., Morgulis, A., Schäffer, A. A., et al. (2005). Protein database searches using compositionally adjusted substitution matrices. FEBS J. 272, 5101-5109. doi: 10.1111/j.17424658.2005.04945.x

Bailey, T. L., Boden, M., Buske, F., Frith, M., Grant, C. E., Clementi, L., et al. (2009). MEME suite: tools for motif discovery and searching. Nucleic Acids Res. 37, 202-208. doi: 10.1093/nar/gkp335

Balogh, B., Canteros, B. I., Stall, R. E., and Jones, J. B. (2008). Control of citrus canker and citrus bacterial spot with bacteriophages. Plant Dis. 92, 1048-1052. doi: 10.1094/PDIS-92-7-1048

Balogh, B., Jones, J. B., Iriarte, F. B., and Momol, M. T. (2010). Phage therapy for plant disease control. Curr. Pharm. Biotechnol. 11, 48-57. doi: $10.2174 / 138920110790725302$
UV-light, desiccation, application method, and the need of a large quantities of phages. Especially the phyllosphere is a harsh environment for phages, making leaf diseases difficult to treat (Gill and Abedon, 2003; Goodridge, 2004; Iriarte et al., 2012). This study indicates that phage therapy is able to reduce bacterial blight symptoms in leek, but to improve the efficacy of the phages in the field, phage persistence in the plant phyllosphere should be improved by the use of protective formulations, addition of non-pathogenic phage-propagating bacterial strains or adapting timing and frequency of application as suggested previously (Jones et al., 2007; Balogh et al., 2010).

\section{AUTHOR CONTRIBUTIONS}

Conceived and designed the experiments: SR, AV, JV, MM, RL. Performed the experiments: SR, AV, SV, BD, DV, CA, CV, HJ, YB, JN, JK. Analyzed the data: SR, DV, YB, MM, RL. Contributed reagents/materials/analysis tools: JN, JK, MM, RL. Wrote the paper: SR. All authors read and approved the final manuscript.

\section{ACKNOWLEDGMENTS}

The authors would like to thank Dr. LS van Overbeek of Wageningen UR (The Netherlands) for providing strain P55. The first author would like to thank Mr. Thijs van den Brande for his help with some of the figures and Mr. Johan Dick and Mrs. Cindy Elisabeth for taking care of the plants. The research was funded by the Agency for Innovation by Science and Technology (IWT, project nr.100881) with co-funding of Boerenbond, INGRO crba, LAVA cvba, and the seed companies Bejo, Enza, Nunhems, Hazera, Rijk Zwaan, and Syngenta.

\section{SUPPLEMENTARY MATERIAL}

The Supplementary Material for this article can be found online at: http://journal.frontiersin.org/article/10.3389/fmicb. 2016.00279

Balogh, B., Jones, J. B., Momol, M. T., Olson, S. M., Obradovic, A., King, P., et al. (2003). Improved efficacy of newly formulated bacteriophages for management of bacterial spot on tomato. Plant Dis. 87, 949-954. doi: 10.1094/PDIS.2003.87.8.949

Barbosa, C., Venail, P., Holguin, A. V., and Vives, M. J. (2013). Co-evolutionary dynamics of the Bacteria Vibrio Sp. CV1 and phages V1G, V1P1, and V1P2: implications for phage therapy. Microb. Ecol. 66, 897-905. doi: 10.1007/s00248013-0284-2

Beale, G. H. (1948). A method for the measurement of mutation rate from phage sensitivity to phage resistance in Escherichia coli. J. Gen. Microbiol. 2, 131-142. doi: 10.1099/00221287-2-2-131

Besemer, J., Lomsadze, A., and Borodovsky, M. (2001). GeneMarkS: a self-training method for prediction of gene starts in microbial genomes. implications for finding sequence motifs in regulatory regions. Nucleic Acids Res. 29, 2607-2618. doi: 10.1093/nar/29.12.2607

Boulé, J., Sholberg, P. L., Lehman, S., M., O’gorman, D. T., and Svircev, A. M. (2011). Isolation and characterization of eight bacteriophages infecting Erwinia amylovora and their potential as biological control agents in British Columbia, Canada. Can. J. Plant Pathol. 33, 308-317. doi: 10.1080/07060661.2011. 588250 
Ceyssens, P. J., Miroshnikov, K., Mattheus, W., Krylov, V., Robben, J., Noben, J. P., et al. (2009). Comparative analysis of the widespread and conserved PB1-like viruses infecting Pseudomonas aeruginosa. Environ. Microbiol. 11, 2874-2883. doi: 10.1111/j.1462-2920.2009.02030.x

Cooksey, D. A. (1994). Molecular mechanisms of copper resistance and accumulation in bacteria. FEMS Microbiol. Rev. 14, 381-386. doi: 10.1111/j.1574-6976.1994.tb00112.x

Criscuolo, A., and Gribaldo, S. (2010). BMGE (Block Mapping and Gathering with Entropy): a new software for selection of phylogenetic informative regions from multiple sequence alignments. BMC Evol. Biol. 10:210. doi: 10.1186/1471-214810-210

Czajkowski, R. (2016). Bacteriophages of soft rot enterobacteriaceae - a minireview. FEMS Microbiol. Lett. 363:fnv230. doi: 10.1093/femsle/fnv230

Debarbieux, L., Leduc, D., Maura, D., Morello, E., Criscuolo, A., Grossi, O. L., et al. (2010). Bacteriophages can treat and prevent Pseudomonas aeruginosa lung infections. J. Infect. Dis. 201, 1096-1104. doi: 10.1086/651135

Flaherty, J. E., Jones, J. B., Harbaugh, B. K., Somodi, G. C., and Jackson, L. E. (2000). Control of bacterial spot on tomato in the greenhouse and field with $\mathrm{H}$-mutant bacteriophages. HortScience 35, 882-884.

Frampton, R. A., Taylor, C., Holguín Moreno, A. V., Visnovsky, S. B., Petty, N. K., Pitman, A. R., et al. (2014). Identification of bacteriophages for biocontrol of the kiwifruit canker phytopathogen Pseudomonas syringae pv. actinidiae. Appl. Environ. Microbiol. 80, 2216-2228. doi: 10.1128/AEM.00062-14

Fujiwara, A., Fujisawa, M., Hamasaki, R., Kawasaki, T., Fujie, M., and Yamada, T. (2011). Biocontrol of Ralstonia solanacearum by treatment with lytic bacteriophages. Appl. Environ. Microbiol. 77, 4155-4162. doi: 10.1128/AEM.02847-10

Gautheret, D., and Lambert, A. (2001). Direct RNA motif definition and identification from multiple sequence alignments using secondary structure profiles. J. Mol. Biol. 313, 1003-1011. doi: 10.1006/jmbi.2001.5102

Gill, J., and Abedon, S. T. (2003). Bacteriophage ecology and plants. APSnet. doi: 10.1094/APSnetFeature-2003-1103. [Epub ahead of print].

Gill, J. J., and Hyman, P. (2010). Phage choice, isolation, and preparation for phage therapy. Curr. Pharm. Biotechnol. 11, 2-14. doi: 10.2174/138920110790725311

Gill, J. J., Svircev, A. M., Smith, R., and Castle, A. J. (2003). Bacteriophages of Erwinia amylovora. Appl. Environ. Microbiol. 69, 2133-2138. doi: 10.1128/AEM.69.4.2133-2138.2003

Glynos, P. E., and Alivizatos, A. S. (2006). Leek rot caused by Pseudomonas syringae pv. porri. Ann. Benaki Phytopathol. Inst. 20, 82-87.

Goodridge, L. D. (2004). Bacteriophage biocontrol of plant pathogens: fact or fiction? Trends Biotechnol. 22, 384-385. doi: 10.1016/j.tibtech.2004.05.007

Goto, M. (1972). Bacterial leaf blight of onion in Japan. Plant Dis. Rep. 56, 490-493.

Hale, C. N. (1975). Bacteriosis of leek in New Zealand. J. Agric. Res. 18, 251-254. doi: 10.1080/00288233.1975.10423640

Henry, M., Bobay, L. M., Chevallereau, A., Saussereau, E., Ceyssens, P. J., and Debarbieux, L. (2015). The search for therapeutic bacteriophages uncovers one new subfamily and two new genera of Pseudomonas-infecting Myoviridae. PLoS ONE 10:e0117163. doi: 10.1371/journal.pone.0117163

Hockett, K. L., Burch, A. Y., and Lindow, S. E. (2013). Thermo-regulation of genes mediating motility and plant interactions in Pseudomonas syringae. PLoS ONE 8:e59850. doi: 10.1371/journal.pone.0059850

Hwang, M. S. H., Morgan, R. L., Sarkar, S. F., Wang, P. W., and Guttman, D. S. (2005). Phylogenetic characterization of virulence and resistance phenotypes of Pseudomonas syringae. Appl. Environ. Microbiol. 71, 5182-5191. doi: 10.1128/AEM.71.9.5182-5191.2005

Ikene, I., Grondeau, C., Bureau, C., and Samson, R. (2003). "Pseudomonas leek blight: study of seed transmission," in Pseudomonas Syringae and Related Pathogens, eds N. S. lacobellis, A. Collmer, S. W. Hutcheson, J. W. Mansfield, C. E. Morris, J. Murillo, N. W. Schaad, D. E. Stead, G. Surico, and M. S. Ullrich (Dordrecht: Springer), 93-95. doi: 10.1007/978-94-017-0133-4_10

Iriarte, F. B., Obradovic, A., Wernsing, M. H., Jackson, L. E., Balogh, B., Hong, J. A., et al. (2012). Soil-based systemic delivery and phyllosphere in vivo propagation of bacteriophages: two possible strategies for improving bacteriophage persistence for plant disease control. Bacteriophage 2, 215-224. doi: 10.4161/bact.23530

Jang, H. B., Fagutao, F. F., Nho, S. W., Park, S. B., Cha, I. S., Yu, J. E., et al. (2013). Phylogenomic network and comparative genomics reveal a diverged member of the KZ-related group, marine Vibrio phage JM-2012. J. Virol. 87, 12866-12878. doi: 10.1128/JVI.02656-13

Janse, J. D. (1982). Enkele nieuw waargenomen aantastingen van Pseudomonas syringae. Verslagen En Mededelingen Plantenziektenkundige Dienst. 158, 34-35.

Jones, J. B., Jackson, L. E., Balogh, B., Obradovic, A., Iriarte, F. B., and Momol, M. T. (2007). Bacteriophages for plant disease control. Annu. Rev. Phytopathol. 45, 245-262. doi: 10.1146/annurev.phyto.45.062806.094411

Kasman, L. M., Kasman, A., Westwater, C., Dolan, J., Schmidt, M. G., and Norris, J. S. (2002). Overcoming the phage replication threshold: a mathematical model with implications for phage therapy. J. Virol. 76, 5557-5564. doi: 10.1128/JVI.76.11.5557-5564.2002

Kelley, L. A., and Sternberg, M. J. E. (2009). Protein structure prediction on the web: a case study using the phyre server. Nat. Protoc. 4, 363-371. doi: 10.1038 /nprot.2009.2

Koike, S. T., Barak, J. D., Hendersen, D. M., and Gilbertson, R. L. (1999). Bacterial blight of leek: a new disease in California caused by Pseudomonas syringae. Plant Dis. 83, 165-170. doi: 10.1094/PDIS.1999.83.2.165

Kropinski, A. M., Prangishvili, D., and Lavigne, R. (2009). Position paper: the creation of a rational scheme for the nomenclature of viruses of bacteria and archaea. Environ. Microbiol. 11, 2775-2777. doi: 10.1111/j.14622920.2009.01970.x

Laslett, D., and Canback, B. (2004). ARAGORN, a program to detect tRNA genes and tmRNA genes in nucleotide sequences. Nucleic Acids Res. 32, 11-16. doi: 10.1093/nar/gkh152

Lavigne, R., Ceyssens, P. J., and Robben, J. (2009a). “Chapter 14 phage proteomics: applications of mass spectrometry," in Bacteriophages Methods and Protocols, Vol. 2, eds M. R. J. Clokie and A. Kropinski (Dordrecht: Humana Press), 239-251.

Lavigne, R., Darius, P., Summer, E. J., Seto, D., Mahadevan, P., Nilsson, A. S., et al. (2009b). Classification of Myoviridae bacteriophages using protein sequence similarity. BMC Microbiol. 9:224. doi: 10.1186/1471-2180-9-224

Lavigne, R., Seto, D., Mahadevan, P., Ackermann, H. W., and Kropinski, A. M. (2008). Unifying classical and molecular taxonomic classification: analysis of the podoviridae using BLASTP-based tools. Res. Microbiol. 159, 406-414. doi: 10.1016/j.resmic.2008.03.005

Lavigne, R., Sun, W. D., and Volckaert, G. (2004). PHIRE, a deterministic approach to reveal regulatory elements in bacteriophage genomes. Bioinformatics 20, 629-635. doi: 10.1093/bioinformatics/btg456

Le, S., He, X., Tan, Y., Huang, G., Zhang, L., Lux, R., et al. (2013). Mapping the tail fiber as the receptor binding protein responsible for differential host specificity of Pseudomonas aeruginosa bacteriophages PaP1 and JG004. PLoS ONE 8:e68562. doi: 10.1371/journal.pone.0068562

Lelliott, R. A. (1952). A new bacterial disease of leeks. Plant Pathol. 1, 84-85. doi: 10.1111/j.1365-3059.1952.tb00035.x

Lima-Mendez, G., Van Helden, J., Toussaint, A., and Leplae, R. (2008). Reticulate representation of evolutionary and functional relationships between phage genomes. Mol. Biol. Evol. 25, 762-777. doi: 10.1093/molbev/msn023

Liu, M., Gingery, M., Doulatov, S. R., Liu, Y., Hodes, A., Baker, S., et al. (2004). Genomic and genetic analysis of Bordetella bacteriophages encoding reverse transcriptase-mediated tropism-switching cassettes. Society 186, 1503-1517. doi: $10.1128 /$ jb.186.5.1503-1517.2004

Lowe, T. M., and Eddy, S. R. (1997). tRNAscan-SE: a program for improved detection of transfer RNA genes in genomic sequence. Nucleic Acids Res. 25, 955-964. doi: 10.1093/nar/25.5.0955

Lukashin, A. V., and Borodovsky, M. (1998). GeneMark.hmm: new solutions for gene finding. Nucleic Acids Res. 26, 1107-1115. doi: 10.1093/nar/26.4.1107

Macke, T. J., Ecker, D. J., Gutell, R. R., Gautheret, D., Case, D. A., and Sampath, R. (2001). RNAMotif, an RNA secondary structure definition and search algorithm. Nucleic Acids Res. 29, 4724-4735. doi: 10.1093/nar/29.22.4724

Myung, I. S., Joa, J. H., and Shim, H. S. (2011). Bacterial leaf spot of onion caused by Pseudomonas syringae pv. porri, a new disease in Korea. Plant Dis. 95, 1311. doi: 10.1094/PDIS-03-11-0250

Myung, I. S., Lee, Y. K., and Shim, H. (2012). Bacterial blight of shallot, caused by Pseudomonas syringae pv. porri, a new disease in Korea. Plant Pathol. J. 28, 454. doi: 10.5423/PPJ.DR.08.2011.0149

Noble, D. H., Cother, E. J., Hailstones, D. L., Flack, M., Oxspring, L., and Hall, B. (2006). Characterisation of Pseudomonas syringae strains associated with 
a leaf disease of leek in Australia. Eur. J. Plant Pathol. 115, 419-430. doi: 10.1007/s10658-006-9033-4

Penadés, J. R., Chen, J., Quiles-Puchalt, N., Carpena, N., and Novick, R. P. (2015). Bacteriophage-mediated spread of bacterial virulence genes. Curr. Opin. Microbiol. 23, 171-178. doi: 10.1016/j.mib.2014.11.019

Petty, N. K., Foulds, I. J., Pradel, E., Ewbank, J. J., and Salmond, G. P. C. (2006). A generalized transducing phage (phiIF3) for the genomically sequenced Serratia marcescens strain Db11: a tool for functional genomics of an opportunistic human pathogen. Microbiology 152, 1701-1708. doi: 10.1099/mic.0.28712-0

Pietrzak, U., and McPhail, D. C. (2004). Copper accumulation, distribution and fractionation in vineyard soils of Victoria, Australia. Geoderma 122, 151-166. doi: 10.1016/j.geoderma.2004.01.005

Ravensdale, M., Blom, T. J., Gracia-Garza, J. A., Svircev, A. M., and Smith, R. J. (2007). Bacteriophages and the control of Erwinia carotovora subsp. carotovora. Can. J. Plant Pathol. 29, 121-130. doi: 10.1080/07060660709507448

Rombouts, S., Van Vaerenbergh, J., Volckaert, A., Baeyen, S., De Langhe, T., Declercq, B., et al. (2015). Isolation and characterization of Pseudomonas syringae pv. porri from Leek in Flanders. Eur. J. Plant Pathol. 144, 185-198. doi: 10.1007/s10658-015-0761-1

Sambrook, J., and Russell, D. (2001). Molecular Cloning: A Laboratory Manual. Cold Spring Harbor, NY: Laboratory Press.

Samson, R., Shafik, H., Benjama, A., and Gardan, L. (1998). Description of the bacterium causing blight of leek as Pseudomonas syringae pv. porri (pv. Nov.). Phytopathology 88, 844-850. doi: 10.1094/PHYTO.1998.88.8.844

Sillankorva, S., Oliveira, R., Vieira, M. J., Sutherland, I., and Azeredo, J. (2004). Pseudomonas fluorescens infection by bacteriophage $\Phi$ s1: the influence of temperature, host growth phase and media. FEMS Microbiol. Lett. 241, 13-20. doi: 10.1016/j.femsle.2004.06.058

Tamura, K., Peterson, D., Peterson, N., Stecher, G., Nei, M., and Kumar, S. (2011). MEGA5: molecular evolutionary genetics analysis using maximum likelihood, evolutionary distance, and maximum parsimony methods. Mol. Biol. Evol. 28, 2731-2739. doi: 10.1093/molbev/ msr121

van Overbeek, L. S., Nijhuis, E. H. M., Koenraadt, H., Visser, J., and van Kruistum, G. (2010). The role of crop waste and soil in Pseudomonas syringae pv. porri infection of leek (Allium Porrum). Appl. Soil Ecol. 46, 457-463. doi: 10.1016/j.apsoil.2010.09.004

Varvaro, L. (1983). Una batteriosi del porro Allium porrum in Puglia. Phytophatol. Mediterr. 22, 86-88.

Conflict of Interest Statement: The authors declare that the research was conducted in the absence of any commercial or financial relationships that could be construed as a potential conflict of interest.

Copyright (๑) 2016 Rombouts, Volckaert, Venneman, Declercq, Vandenheuvel, Allonsius, Van Malderghem, Jang, Briers, Noben, Klumpp, Van Vaerenbergh, Maes and Lavigne. This is an open-access article distributed under the terms of the Creative Commons Attribution License (CC BY). The use, distribution or reproduction in other forums is permitted, provided the original author(s) or licensor are credited and that the original publication in this journal is cited, in accordance with accepted academic practice. No use, distribution or reproduction is permitted which does not comply with these terms. 